\title{
Embolia Aérea Arterial durante Anestesia para Marcação Percutânea de Nódulo Pulmonar. Relato de Caso *
}

\section{Arterial Air Embolism during Anesthesia for Percutaneous Pulmonary Node Location. Case Report}

Mônica Rossi Rodrigues ${ }^{1}$, Renato Ângelo Saraiva, TSA ${ }^{2}$

\section{RESUMO}

Rodrigues MR, Saraiva RA - Embolia Aérea Arterial durante Anestesia para Marcação Percutânea de Nódulo Pulmonar. Relato de Caso

Justificativa e Objetivos - A embolia aérea arterial é uma complicação que pode ocorrer durante diversos tipos de procedimentos cirúrgicos e está relacionada à alta incidência de morbidade e mortalidade. O objetivo deste relato é mostrar um caso de embolia aérea arterial durante anestesia geral para marcação percutânea de nódulo pulmonar guiada por tomografia computadorizada.

Relato do Caso - Paciente de 33 anos, do sexo masculino, estado físico ASA II, foi submetido à marcação percutânea de nódulo pulmonar (provável metástase de tumor de células gigantes do fêmur) com agulha gancho, sob anestesia geral. A indução anestésica foi realizada sem dificuldades e com o paciente em decúbito lateral direito, o procedimento foi iniciado. Após a instalação do gancho, enquanto os cirurgiões verificavam seu posicionamento com novas imagens de tomografia, foram observadas hipotensão arterial e bradicardia, seguidas de assistolia. Foram realizadas manobras de reanimação, drenagem torácica e ecocardiografia transtorácica. Em um dos cortes tomográficos mais recentes foi visualizada presença de ar no interior da aorta descendente. Após 15 minutos de reanimação houve reversão do quadro. O paciente foi encaminhado à UTI e 6 dias após recebeu alta hospitalar sem seqüelas.

Conclusões - A embolia aérea arterial é uma complicação de vários procedimentos e na maioria deles o paciente está sob anestesia geral. O anestesiologista deve estar preparado para reconhecer as alterações envolvidas e fazer o diagnóstico diferencial. A instituição de medidas terapêuticas oportunas e adequadas são fundamentais para a redução da morbidade e da mortalidade decorrentes deste evento.

UNITERMOS: COMPLICAÇÕES: embolia aérea

\footnotetext{
* Recebido do (Received from) Hospital SARAH Brasilia, DF

1. Anestesiologista da Rede SARAH de Hospitais do Aparelho Locomotor

2. Coordenador de Anestesiologia da Rede SARAH de Hospitais do Aparelho Locomotor
}

Apresentado (Submitted) em 09 de abril de 2002

Aceito (Accepted) para publicação em 11 de junho de 2002

Correspondência para (Mail to):

Dr. Renato Ângelo Saraiva

SMHS Quadra 501 - Conjunto: A

70335-901 Brasilia, DF

(c) Sociedade Brasileira de Anestesiologia, 2003

\section{SUMMARY}

Rodrigues MR, Saraiva RA - Arterial Air Embolism during Anesthesia for Percutaneous Pulmonary Node Location. Case Report

Background and Objectives - Arterial air embolism is a complication that may occur during several surgical procedures and is associated to a high morbidity and mortality rate. This report aimed at presenting a case of arterial air embolism during general anesthesia for percutaneous CT-guided location of a pulmonary node.

Case Report - Male patient, 33 years old, physical status ASA II, was submitted to percutaneous location of a pulmonary node (probably a femoral giant cell tumor metastasis) with the hook-wire technique under general anesthesia. Anesthesia was induced without difficulties and the procedure was started with the patient in the right lateral position. After hook insertion, while the surgeons checked its positioning with CT images, arterial hypotension and bradycardia followed by asystole was observed. Cardiopulmonary resuscitation maneuvers, thoracic drainage and transthoracic echocardiography were performed. The presence of air in the descending aorta was seen at a later CT image. Cardiac arrest was reversed 15 minutes after resuscitation maneuvers. Patient was referred to the ICU and discharged 6 days later without sequelae.

Conclusions - Arterial air embolism is a complication of different procedures most of them performed with the patient under general anesthesia. Anesthesiologists must be prepared to recognize involved problems and make the differential diagnosis. Suitable and adequate treatment is critical to decrease morbidity and mortality associated to this event.

KEY WORDS: COMPLICATIONS: air embolism

\section{INTRODUÇÃO}

embolia aérea arterial é comumente descrita como uma Acomplicação de procedimentos com circulação extracorpórea ou de trauma torácico ${ }^{1,2}$.

Foram relatados vários casos de embolia arterial sistêmica em pacientes submetidos à biópsia, por agulha, de lesões pulmonares sob anestesia geral e ventilação com pressão positiva $^{2-4}$.

O objetivo deste relato é apresentar um caso de embolia arterial sistêmica com colapso cardiovascular em um paciente submetido à marcação percutânea de nódulo pulmonar sob anestesia geral.

\section{RELATO DO CASO}

Paciente do sexo masculino, 33 anos, portador de tumor de células gigantes no fêmur direito tratado cirurgicamente, apresentando à tomografia computadorizada (TC) de tórax, 
nódulo na região basal do lobo pulmonar inferior esquerdo, sugestivo de metástase.

Foi indicada marcação percutânea do nódulo com aguIha-gancho guiada por TC seguida de ressecção cirúrgica por toracoscopia vídeo-assistida.

$\mathrm{Na}$ consulta pré-anestésica ambulatorial foi classificado como estado físico ASA II devido à patologia cirúrgica. Não estava em uso de medicamentos. Apresentava antecedentes de anestesia geral e peridural sem intercorrências. Os exames laboratoriais pré-operatórios estavam dentro da normalidade.

Foi proposta anestesia geral balanceada no setor de radiologia. Após a marcação do nódulo seria encaminhado ao centro cirúrgico para ser submetido à ressecção por toracoscopia.

Na visita pré-anestésica apresentava níveis pressóricos elevados, apesar de não haver relato de hipertensão arterial. O procedimento não foi adiado por se tratar de cirurgia oncológica (provável metástase).

Como medicação pré-anestésica foram administrados, por via oral, $10 \mathrm{mg}$ de diazepam na noite anterior e $15 \mathrm{mg}$ de midazolam 30 minutos antes da indução anestésica.

Após monitorização com ECG contínuo, oxímetro de pulso e aparelho de pressão arterial não-invasiva, foi realizada venóclise com cateter $16 \mathrm{G}$ no membro superior direito. Após oxigenação prévia foi feita indução venosa com etomidato $(0,3$ $\left.\mathrm{mg} \cdot \mathrm{kg}^{-1}\right)$, fentanil $\left(5 \mu \mathrm{g} \cdot \mathrm{kg}^{-1}\right)$ e vecurônio $\left(0,1 \mathrm{mg} \cdot \mathrm{kg}^{-1}\right)$, laringoscopia e intubação traqueal com tubo Robert Shaw esquerdo $n^{\circ} 35 \mathrm{~F}$. A manutenção da anestesia foi feita com isoflurano (0,5 a $1 \mathrm{CAM}$ ), $\mathrm{F}_{1} \mathrm{O}_{2}$ de $60 \%$ (mistura de oxigênio e ar atmosférico a 1:1 L. $\mathrm{min}^{-1}$ ) em ventilação controlada mecânica.

Com o paciente em decúbito lateral direito foram iniciados os cortes tomográficos preliminares para localização do nódulo, com os pulmões em inspiração sustentada. Em seguida, o cirurgião realizou a marcação do nódulo com gancho padrão introduzido através de agulha $20 \mathrm{G}(0,9 \mathrm{~mm} \times 9 \mathrm{~cm})$ (U.S. Biopsy, Franklin, IN), conforme os parâmetros obtidos pela TC. Durante a verificação do posicionamento do gancho, com novas imagens tomográficas dos pulmões insuflados, o paciente, que vinha mantendo estabilidade hemodinâmica e ventilatória, apresentou subitamente hipotensão arterial grave (54 x $30 \mathrm{mmHg}$ ), bradicardia e diminuição da $\mathrm{P}_{\mathrm{ET}} \mathrm{CO}_{2}$. O quadro evoluiu rapidamente para assistolia, quando foram iniciadas as manobras de reanimação, com ventilação controlada manual, com $\mathrm{FiO}_{2}$ de $100 \%$, e massagem cardíaca externa.

Foi observada presença de secreção sanguinolenta no interior do tubo, no ramo brônquico. Concomitante às manobras de reanimação, foi realizada drenagem do hemitórax esquerdo sem evidência de pneumotórax nem hemotórax.

Na reavaliação das imagens da TC mais recentes, foi possível a visualização de ar no interior da aorta descendente (Figura 1).

O paciente foi colocado na posição de cefalodeclive e os procedimentos de reanimação continuados. Após aproximadamente 15 minutos de reanimação observou-se atividade elétrica (taquicardia sinusal) e presença de pulso em grandes

Revista Brasileira de Anestesiologia

Vol. 53, № 1, Janeiro - Fevereiro, 2003

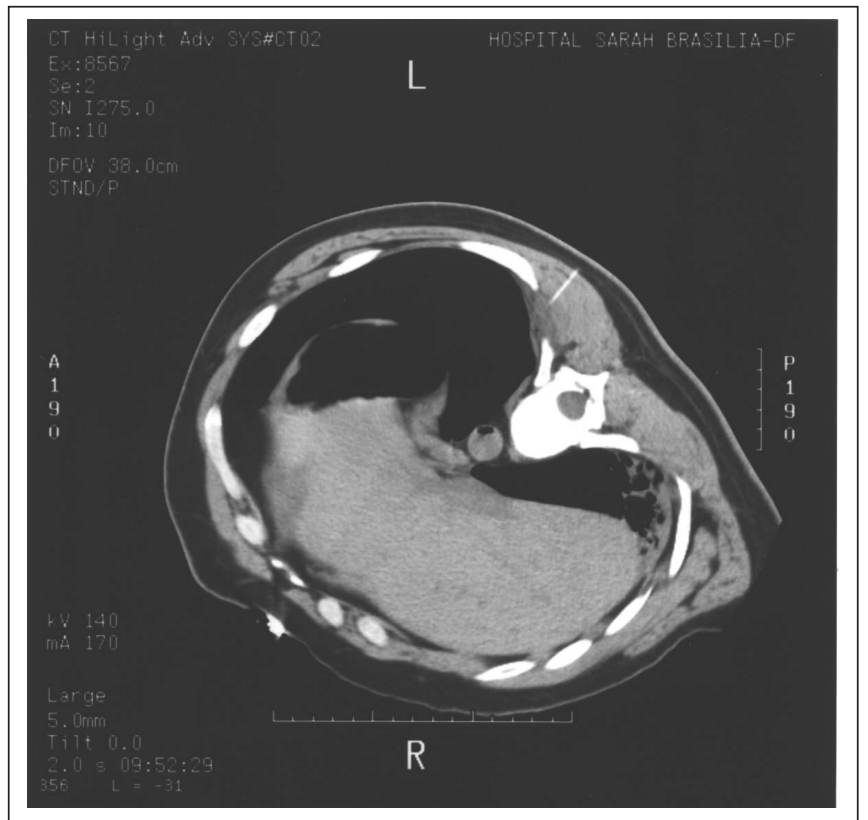

Figura 1 - Imagem da tomografia computadorizada mostrando corte no nível de T10 onde estão visíveis o lobo direito do fígado (clara), as bases pulmonares e a bolha gasosa do estômago (escuras) e o corpo vertebral (clara). No interior da aorta (imagem redonda clara), situada entre o corpo vertebral e o fígado, pode ser vista a bolha de ar (escura)

artérias. No total, foram administrados $4 \mathrm{mg}$ de epinefrina em doses fracionadas e $0,5 \mathrm{mg}$ de atropina, por via venosa.

Foi realizada ecocardiografia transtorácica, que não evidenciou presença de ar nas câmaras cardíacas nem nos grandes vasos.

Foi iniciada infusão de dopamina $\left(3 \mu \mathrm{g} \cdot \mathrm{kg}^{-1} \cdot \mathrm{min}^{-1}\right)$ pela veia jugular externa esquerda.

Trinta minutos após o restabelecimento do ritmo cardíaco e da circulação, o paciente começou a apresentar deglutição e movimentos respiratórios. As pupilas estavam médias, isocóricas e fotorreagentes.

Após sedação e curarização, o tubo de duplo lúmen foi substituído por um simples e o paciente encaminhado, hemodinamicamente estável e em ventilação controlada manual, à unidade de terapia intensiva (UTI).

Seis horas após a entrada na UTI, o paciente apresentava-se intubado, em desmame da ventilação mecânica, sem drogas vasoativas e sem sedação. Ao exame estava alerta, comunicando-se coerentemente com o examinador, sem sinais de alterações cognitivas ou qualquer outro déficit neurológico. Foi extubado no dia seguinte.

Dois dias após, foi submetido à toracotomia para ressecção do nódulo e do gancho, tendo recebido alta hospitalar no $4^{\circ}$ dia do pós-operatório.

\section{DISCUSSÃO}

A cirurgia toracoscópica vídeo-assistida é uma alternativa menos invasiva à toracotomia convencional para ressecção de nódulos pulmonares periféricos ${ }^{5}$. A principal limitação da 
técnica é a dificuldade de localização do nódulo alvo ${ }^{6,7}$. Entre os vários métodos propostos, um dos mais eficientes é a marcação pré-operatória do nódulo com uma agulha-gancho guiada por tomografia computadorizada ${ }^{5-7}$.

Na literatura, a técnica é considerada segura e relacionada à baixa morbidade, com a descrição de complicações relativamente leves como pneumotórax e pequenas hemorragias intrapulmonares ${ }^{5-7}$.

A ocorrência de embolia arterial sistêmica durante biópsia pulmonar aberta e percutânea já foi relatada ${ }^{2-4}$.

Procedimentos percutâneos com agulhas $20 \mathrm{G}$ ou de menor calibre são considerados seguros, apesar de existir relato de embolia aérea cerebral após aspiração transtorácica com agulha $23 \mathrm{G}^{2,3,8}$

Em relação ao manuseio da anestesia, a técnica cirúrgica não requer procedimentos ou cuidados diferentes dos necessários na cirurgia torácica convencional. A possibilidade de ocorrerem complicações impõe a necessidade de vigilância constante e o conhecimento dos eventos que deverão ser cogitados no diagnóstico diferencial.

O reconhecimento da embolia aérea arterial no paciente anestesiado é sugerido pela observação de colapso cardiovascular e de secreção sanguinolenta e espumosa no circuito ventilatório ${ }^{1-3}$.

A principal ameaça da presença de ar no sistema arterial é o risco de embolização para a circulação coronariana ou cerebral. A embolização de ar para as artérias coronárias pode ser fatal, porque a interrupção do fluxo sangüíneo pode desencadear disritmias induzidas pela isquemia, infarto do miocárdio ou ambos. No caso da circulação cerebral, a embolia aérea pode causar isquemia cerebral, podendo ocorrer de alterações neurológicas transitórias, que duram dias, a infarto cerebral completo ${ }^{1}$.

Os exames complementares que auxiliam no diagnóstico são a ecocardiografia e o doppler transtorácico, transesofágico e transcraniano ${ }^{1,2}$.

O exame fundoscópico da retina pode revelar a presença de ar no interior dos vasos.

A diminuição abrupta do $\mathrm{CO}_{2}$ expirado pode ocorrer como conseqüência da diminuição do débito cardíaco ${ }^{2}$.

Tomografia de tórax com imagem de ar intravascular ou intracardíaco em paciente vivo nunca foi relatada ${ }^{2}$.

O tratamento depende do órgão envolvido. Neste caso, o paciente apresentou colapso cardiovascular provavelmente devido ao comprometimento da circulação coronariana. Aterapia consiste em restabelecer a contratilidade miocárdica, em remover o ar quando for possível e em tratamento imediato com oxigênio hiperbárico, para reduzir o volume das bolhas na circulação periférica. Utilizam-se também agentes inotrópicos para elevar a pressão aórtica, especialmente a diastólica, e incrementar a perfusão através das coronárias parcialmente obstruídas ${ }^{3}$.

$\mathrm{Na}$ embolia cerebral, a oxigenioterapia hiperbárica pode reduzir a quantidade de ar nos tecidos e o deficit neurológico. Outras medidas incluem o uso de anti-convulsivantes, corticosteróides e anti-agregantes plaquetários ${ }^{3}$.
Este paciente não apresentou nenhuma seqüela neurológica evidente. $O$ decúbito lateral direito pode ter facilitado a migração do ar embolizado pela curva interna do arco aórtico sem ascender para a circulação cerebral.

Durante a toracotomia à qual o paciente foi submetido posteriormente, foi observado que o gancho havia atravessado um brônquio sub-segmentar, no seu trajeto até o nódulo. Provavelmente a passagem do gancho promoveu a comunicação do brônquio com a vasculatura adjacente e a conseqüente penetração de ar em uma veia pulmonar e no átrio esquerdo durante a inspiração com pressão positiva, quando a pressão para inflar o alvéolo era maior do que a pressão da veia pulmonar. $\mathrm{Na}$ expiração, a pressão venosa pulmonar maior que a pressão intra-brônquica, permitiu a passagem de sangue para a via aérea e para o tubo.

A embolia aérea arterial pode ocorrer em várias circunstâncias, incluindo cirurgia cardíaca ${ }^{9}$, injeções arteriais ${ }^{10}$, posicionamento de cateter venoso central ${ }^{11}$, laparoscopia ${ }^{12}$, cirurgia torácica ${ }^{13}$, entre outras.

É fundamental para o prognóstico do paciente que os profissionais que lidam com procedimentos com potencial para esta complicação estejam preparados para realizar diagnóstico precoce e instituir rapidamente as medidas terapêuticas recomendadas.

\section{Arterial Air Embolism during Anesthesia for Percutaneous Pulmonary Node Location. Case Report}

Mônica Rossi Rodrigues, M.D., Renato Ângelo Saraiva, TSA, M.D.

\section{INTRODUCTION}

Arterial air embolism is often described as a complication of cardiopulmonary bypass procedure or chest trauma ${ }^{1,2}$. Several systemic air embolism cases were reported in patients submitted to needle biopsy of pulmonary lesions under general anesthesia and positive pressure ventilation ${ }^{2-4}$.

This report aimed at presenting a case of systemic arterial air embolism with cardiovascular collapse in a patient submitted to percutaneous location of a pulmonary node under general anesthesia.

\section{CASE REPORT}

Male patient, 33 years old, suffering from a surgically treated giant cell tumor in the right femur, presented at chest CT-scan a node in the basal region of the lower left pulmonary lobe suggestive of a metastasis.

Percutaneous node location with a CT-guided hook-wire followed by video-assisted thoracoscopy was indicated.

Patient was classified as physical status ASA II at preanesthetic evaluation due to surgical pathology. Patient was not using drugs and had a history of epidural and general 
anesthesia without intercurrences. Preoperative lab tests were normal.

Balanced general anesthesia in the radiology room was proposed. After node location, patient would be transferred to the operating center to be submitted to thoracoscopic resection.

At preanesthetic evaluation patient presented high blood pressure levels, however without arterial hypertension. Procedure was not postponed due to its oncologic nature (possible metastasis).

Patient was premedicated with $10 \mathrm{mg}$ oral diazepam the evening before the procedure and $15 \mathrm{mg}$ midazolam 30 minutes before anesthetic induction.

After continuous ECG monitoring, pulse oximetry and non-invasive blood pressure, a 16G catheter was inserted in the right upper limb. After previous oxygenation, anesthesia was induced with etomidate $\left(0.3 \mathrm{mg} \cdot \mathrm{kg}^{-1}\right)$, fentanyl (5 $\left.\mu \mathrm{g} \cdot \mathrm{kg}^{-1}\right)$ and vecuronium $\left(0.1 \mathrm{mg} \cdot \mathrm{kg}^{-1}\right)$, followed by laryngoscopy and tracheal intubation with a left 35F Robert Shaw tube. Anesthesia was maintained with isoflurane $(0.5$ to $1 \mathrm{MAC}$ ), $60 \% \mathrm{~F}_{1} \mathrm{O}_{2}$ (mixture of oxygen and atmospheric air at $1: 1 \mathrm{~L} . \mathrm{min}^{-1}$ ) in mechanically controlled ventilation.

Preliminary CT images were started with the patient in the right lateral position to locate the node, with lungs in sustained inspiration. Node was then marked by the surgeon with a standard hook inserted through a $20 \mathrm{G}$ needle $(0.9 \mathrm{~mm} \times 9 \mathrm{~cm})$ (U.S. Biopsy, Franklin, IN), according to CT parameters.

While checking hook's position with new CT images of inflated lungs, the patient, who was maintaining hemodynamic and ventilatory stability, presented a sudden and severe arterial hypotension (54 x $30 \mathrm{mmHg}$ ), bradycardia and $\mathrm{P}_{\mathrm{ET}} \mathrm{CO}_{2}$ decrease, rapidly evolving to asystole. Resuscitation maneuvers were started with manually controlled ventilation with $100 \% \mathrm{~F}_{1} \mathrm{O}_{2}$ and external cardiac massage.

A bloody secretion was observed inside the bronchial tube. Together with resuscitation maneuvers, left hemithorax was drained without evidence of pneumothorax or hemithorax.

Later CT images revealed air in the descending aorta (Figure 1). The patient was placed in the head-down position and resuscitation procedures continued. After approximately 15 minutes electric activity (sinusal tachycardia) and pulse in large arteries were observed. In total, $4 \mathrm{mg}$ epinephrine in fractional doses and $0.5 \mathrm{mg}$ intravenous atropine were administered. Transthoracic echocardiography did not reveal air in heart chambers or great vessels.

Dopamine $\left(3 \mu \mathrm{g} \cdot \mathrm{kg}^{-1} \cdot \mathrm{min}^{-1}\right)$ was administered through the left external jugular vein.

Thirty minutes after cardiac rhythm and circulation recovery, patient started swallowing and presented respiratory movements. Pupils were medium, isochoric and photo-reacting. After sedation and curarization, the double-lumen tube was replaced by a single-lumen tube and patient was referred to the intensive care unit (ICU) hemodynamically stable and in manually controlled ventilation.

Six hours after entering the ICU, patient was still intubated, weaning mechanical ventilation, without vasoactive drugs or sedation. Patient was alert, consistently communicating with

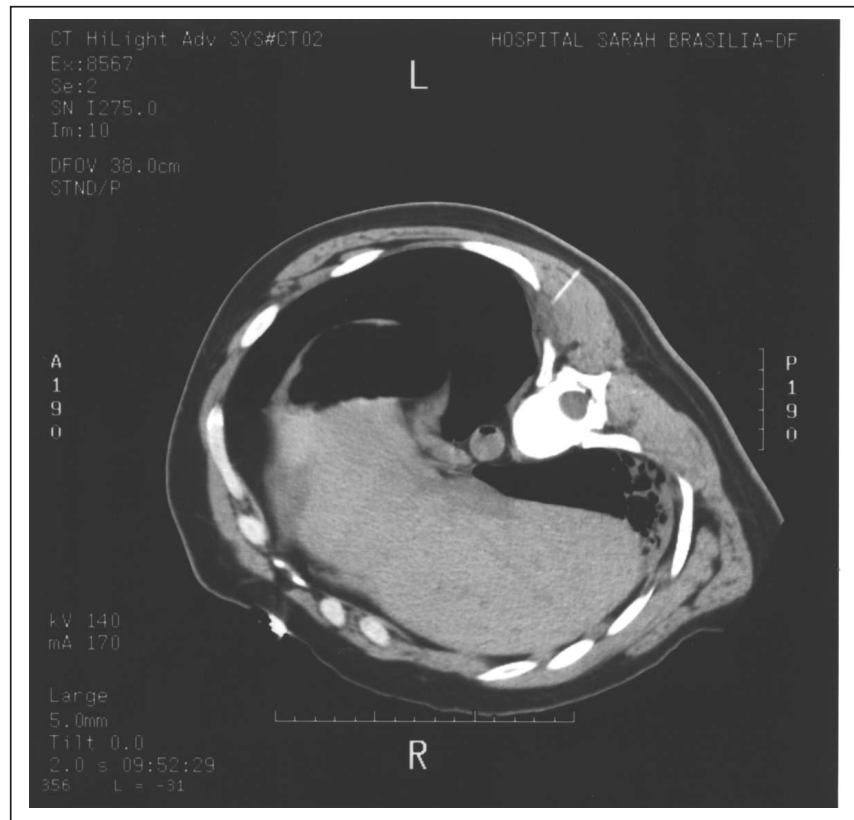

Figure 1 - CT T 10 image showing liver right lobe (light), pulmonary bases and stomach gaseous bulla (dark) and vertebral body (light). Air bubble may be observed (dark) within the aorta (round light image), located between the vertebral body and the liver

the investigator, without cognitive changes or any other neurological deficit. Patient was extubated the next day.

Thoracotomy for node resection and hook removal was performed two days later and patient was discharged in the $4^{\text {th }}$ postoperative day.

\section{DISCUSSION}

Video-assisted thoracoscopy is a less invasive alternative to conventional thoracotomy for peripheral pulmonary node resection ${ }^{5}$. Major limitation is the difficulty in locating the target-node ${ }^{6,7}$. Among several proposed procedures, one of the most efficient is preoperatively marking the node with a CT-guided hook-wire ${ }^{5-7}$. The technique is considered safe and of low morbidity with relatively mild complications such as pneumothorax and minor intrapulmonary hemorrhages ${ }^{5-7}$. Systemic arterial air embolism during open and percutaneous pulmonary biopsy has already been reported ${ }^{2-4}$

Percutaneous procedures with $20 \mathrm{G}$ needles or below are considered safe, although there is a report of brain air embolism after transthoracic aspiration with a $23 \mathrm{G}$ needle ne $^{2,3,8}$. As to anesthesia, the surgical technique does not require different care or procedures from those needed in a conventional thoracic surgery. The possibility of complications mandates continuous surveillance and the knowledge of the events to be considered in the differential diagnosis.

Arterial air embolism identification in anesthetized patients is suggested by the observation of cardiovascular collapse and bloody and bubbly secretion in the ventilation circuit ${ }^{1-3}$.

Amajor threat of the presence of air in the arterial system is the risk of embolization to coronary or brain circulation. Air 
embolization to coronary arteries may be fatal because the interruption of blood flow may trigger ischemia-induced arrhythmias, myocardial infarction or both. In brain circulation, air embolism may cause brain ischemia with transient neurological changes lasting for days or even total brain infarction ${ }^{1}$. Tests helping in the diagnosis are echocardiography and transthoracic, transesophageal and transcranial doppler ${ }^{1,2}$. Retina funduscopy may reveal the presence of air within the vessels.

Sudden expired $\mathrm{CO}_{2}$ decrease may be seen as a consequence of cardiac output decrease ${ }^{2}$.

Chest CT images with intravascular or intracardiac air have never been reported in live patients ${ }^{2}$.

Treatment depends on the involved organ. In our case, patient presented cardiovascular collapse probably due to coronary circulation involvement. Therapy consists in reestablishing myocardial contractility, removing the air when possible and immediate hyperbaric oxygen treatment to decrease the volume of bubbles in the peripheral circulation. Inotropic agents are also used to increase aortic pressure, especially diastolic, and improve perfusion through partially obstructed coronary arteries ${ }^{3}$.

In brain embolism, hyperbaric oxygen therapy may decrease the amount of air in the tissues and neurological deficit. Other measures include anti-convulsants, steroids and anti platelet aggregation agents ${ }^{3}$.

Ourpatient had no apparent neurological sequelae. Right lateral position may have helped migration of embolized air through the internal curve of the aortic arch without ascending to brain circulation.

During thoracotomy, to which the patient was submitted later, it was observed that the hook had crossed a sub-segmental bronchus in its pathway toward the node. It is possible that the hook has promoted a communication of the bronchus with adjacent vasculature and the consequent penetration or air in a pulmonary vein and in the left atrium during positive pressure inspiration, when the pressure to inflate the alveolus was higher than the pulmonary vein pressure. At expiration, venous pulmonary pressure higher than intra-bronchial pressure has allowed blood to migrate to airways and the tube. Arterial air embolism may occur in different circumstances, including heart surgery ${ }^{9}$, arterial injections ${ }^{10}$, central venous catheter positioning ${ }^{11}$, laparoscopy ${ }^{12}$ and thoracic surgeries ${ }^{13}$, among others.

It is critical for patients' prognosis that professionals dealing with procedures potentially risky for such complications be prepared for early diagnosis and prompt treatment.

\section{REFERÊNCIAS - REFERENCES}

01. Bedford RF - Air Embolism, em Gravenstein N, Kirby RR - Complications in Anesthesiology, $2^{\text {nd }}$ Ed, Philadelphia, New York, Lippincott Raven Publishers, 1996;271-280.

02. Ho Anthony $\mathrm{MH}$, Ling $\mathrm{E}$ - Systemic air embolism after lung trauma. Anesthesiology, 1999;90:564-575.

03. Worth ER, Burton RJ, Landreneau RJ et al - Left atrial air embolism during intraoperative needle biopsy of a deep pulmonary lesion. Anesthesiology, 1990;73:342-345
04. Cianci P, Posin JP, Shimshak RR et al - Air embolism complicating percutaneous thin needle biopsy of lung. Chest, 1987;92: 749-751.

05. Shepard JO, Mathisen DJ, Muse VV et al - Needle localization of peripheral lung nodules for video-assisted thoracoscopic surgery. Chest, 1994;105:1559-1563.

06. Gossot D, Miaux Y, Guermazi A et al - The hook-wire technique for localization of pulmonary nodules during thoracoscopic resection. Chest, 1994;105:1467-1469.

07. Mack MJ, Gordon MJ, Postma TW et al - Percutaneous localization of pulmonary nodules for thoracoscopic lung resection. Ann Thorac Surg, 1992;53:1123-1124.

08. Wong RS, Ketai L, Temes T et al - Air embolus complicating transthoracic needle biopsy. Ann Thorac Surg, 1995;59: 1010-1011.

09. Van der Linden J, Casimir-Ahn H - When do cerebral emboli appear during open heart operations? A transcranial Doppler study. Ann Thoracic Surgery, 1991;51:237-241.

10. Rand MV, Richard ARF - Cerebral air embolism occurring at angiography and diagnosed by computerized tomography $\mathrm{J}$. Neurosurg, 1984;60:177-178.

11. Michel L, Poskanzer DC, MacKusick KA et al - Fatal paradoxical air embolism to the brain. Complication of central venous catheterization. JPEN, 1982;6:68-70.

12. Schindler E, Muller M, Kelm C - Cerebral carbon dioxide embolism during laparoscopic cholecystectomy. Anesth Analg, 1995;81: 643-645.

13. Khalil SW, Madan U, Rigor BM et al - Systemic air embolism following induction of artificial pneumothorax under anaesthesia with successful management. Br J Anaesth, 1979;51:561-565.

\section{RESUMEN}

Rodrigues MR, Saraiva RA - Embolia Aérea Arterial durante Anestesia para Marcación Percutánea de Nódulo Pulmonar. Relato de Caso

Justificativa y Objetivos - La embolia aérea arterial es una complicación que puede ocurrir durante diversos tipos de procedimientos quirúrgicos y está relacionada a la alta incidencia de morbidad y mortalidad. El objetivo de este relato es mostrar un caso de embolia aérea arterial durante anestesia general para marcación percutánea de nódulo pulmonar guiada por tomografia computadorizada.

Relato del Caso - Paciente de 33 años, masculino, estado físico ASA II, fue sometido a marcación percutánea de nódulo pulmonar (probable metástasis de tumor de células gigantes del fémur) con aguja gancho, bajo anestesia general. La inducción anestésica fue realizada sin dificultades y con el paciente en decúbito lateral derecho, el procedimiento fue iniciado. Después de la instalación del gancho, en cuanto los cirujanos verificaban su posicionamiento con nuevas imágenes de tomografia, fueron observadas hipotensión arterial y bradicardia, seguidas de asistolia. Fueron realizadas maniobras de reanimación, drenaje torácica y ecocardiografia transtorácica. En uno de los cortes tomográficos más recientes fue visualizada presencia de aire en el interior de la aorta descendiente. Después de 15 minutos de reanimación hubo reversión del cuadro. El paciente fue encaminado a la UTI y 6 días después recibió alta hospitalar sin secuelas.

Conclusiones - La embolia aérea arterial es una complicación de varios procedimientos y en la mayoría de ellos el paciente está bajo anestesia general. El anestesista debe estar preparado para reconocer las alteraciones envolvidas y hacer el diagnóstico diferencial. La institución de medidas terapéuticas oportunas y adecuadas son fundamentales para la reducción de la morbidad y de la mortalidad decurrentes de este evento. 